\title{
Clinical Management of a Complicated Crown-Root Fracture: A Case Report
}

\author{
Sandra Rivera FIDEL ${ }^{1}$ \\ Rivail Antonio Sergio FIDEL-JUNIOR ${ }^{2}$ \\ Luciana Moura SASSONE ${ }^{1}$ \\ Cristiana Francescutti MURAD ${ }^{1}$ \\ Rivail Antonio Sergio FIDEL ${ }^{1}$ \\ ${ }^{1}$ UERJ - Rio de Janeiro State University, Rio de Janeiro, RJ, Brazil \\ ${ }^{2}$ Veiga de Almeida University, Rio de Janeiro, RJ, Brazil
}

\begin{abstract}
This report describes the clinical procedures involved in the treatment of a complicated crown-root fracture in the maxillary left central incisor with a wide open apex of a 10-year-old male patient, due to fall from his own height. Post-trauma treatment comprised cervical pulpotomy and adhesive tooth fragment reattachment. After 1 year, clinical and radiograph examinations showed pulp necrosis and an associated periapical lesion. Endodontic therapy with calcium hydroxide-base intracanal dressing, root canal filling and orthodontic extrusion were performed. Extrusion was completed within approximately 16 weeks and the tooth was restored with a post-core system and a prosthetic crown. After a 3 years of follow-up, there was no evidence of apical periodontitis and the tooth was satisfactory both esthetically and functionally.
\end{abstract}

Key Words: crown-root fracture, traumatic dental injuries, permanent tooth, orthodontic extrusion.

\section{INTRODUCTION}

Traumatic injuries to teeth and their supporting tissues usually occur in young people and damage may vary from enamel fracture to avulsion, with or without pulpal involvement or bone fracture. A crown-root fracture is a type of dental trauma, usually resulting from horizontal impact, which involves enamel, dentin and cementum, occurs below the gingival margin and may be classified as complicated or uncomplicated, depending on whether pulp involvement is present or absent $(1,2)$. Most of these injuries occur in permanent maxillary incisors before complete root formation and cause pulp inflammation or necrosis (1). Epidemiological statistics revealed that crown-root fractures represent $5 \%$ of dental injuries $(1,3)$. Treatment of complicated crownroot fractures is often challenging due to difficulty in achieving isolation with a rubber dam for a dry operating field, which might comprised the hermetic seal (4).

Dentoalveolar trauma during the maturation of permanent teeth may result in incomplete root formation and root resorption (5). The Hertwig's epithelial root sheath may continue the process of root formation, even in the presence of pulp pathologies, if it remains intact $(6,7)$. However, sheath destruction hinders the differentiation of odontoblast-like cells (6). Moreover, several techniques have been developed to induce hard tissue formation and apical closure. Among them, the use of a calcium hydroxide-based paste as an intracanal dressing has been reported to stimulate hard tissue formation and apexification after root canal therapy $(6,8)$.

Several therapeutic procedures can be indicated to treat teeth with complicated crown-root fracture, depending on fracture location $(2,3,9)$. Treatment options of a subgingival or infraosseous fracture include orthodontic or surgical extrusions, gingivectomy and osteotomy and intentional replantation. Orthodontic extrusion expose the fracture line by extruding the tooth with orthodontic forces, very similar to the movements involved in physiological root eruption. in spite of being a costly and time-consuming procedure, it is favorable to the preservation of pulp vitality and gingival health.

Correspondence: Profa. Dra. Sandra Rivera Fidel, Rua Dr Otávio Kelly 63/301, Tijuca, 20511-280 Rio de Janeiro, RJ, Brasil. Tel: +55-21-2587-6455. Fax:+55-21-2568-3056. e-mail: sandrafidel@gmail.com 
In addition, orthodontic extrusion does not involve loss of alveolar bone or periodontal support and produces good aesthetic results (9-11).

This report describes the management of a complicated crown-root fracture by orthodontic root extrusion and apexification with calcium hydroxide-based paste in a young patient, with 3 years of follow-up.

\section{CASE REPORT}

A 10-year-old male child came to the Dental Traumatology Center of the Dental School of Rio de Janeiro State University $16 \mathrm{~h}$ after having fallen and suffering a traumatic injury to the maxillary central incisors. Past medical history was reviewed and there was no remarkable report. A written informed consent form was signed by his parents for treatment and further publication of the case. Clinical examination revealed a complicated crown-root fracture in the left central incisor and concussion of the right central incisor. (Fig. 1). Clinical and radiographic maxillofacial examination revealed that there was no fracture of the maxilla or mandible or other facial bones. Intraoral periapical radiographic investigation revealed loss of coronal tooth structure and presence of an oblique crown-root fracture on the left central incisor and showed that both central incisors presented incomplete apex formation (Fig. 2).

Pulp vitality of the maxillary right and left incisors was checked using an electric pulp tester (Parkell, Edgewood, NY, USA) and thermal tests (Endofrost, Roeko, Germany). The maxillary left central incisor showed slightly positive response to both tests, whereas the right central incisor showed positive response. Due to the pulp condition and stage of root development,

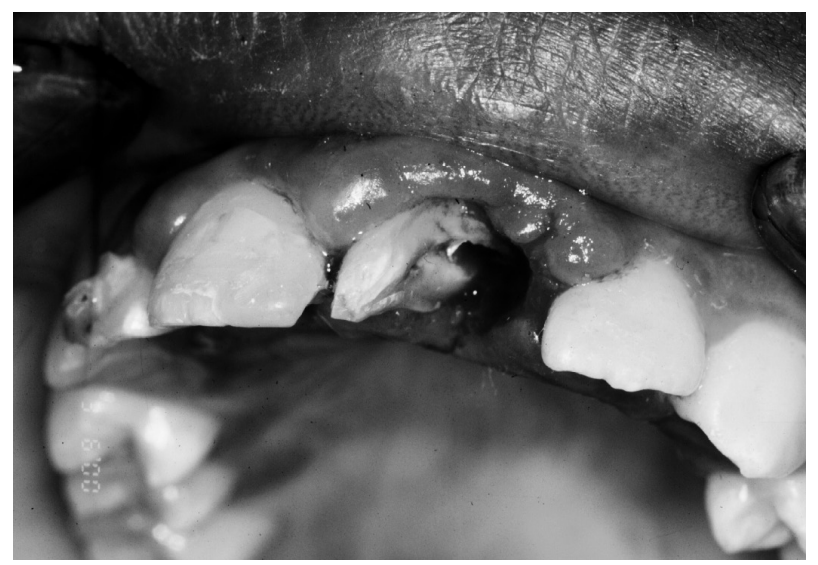

Figure 1. Intraoral view of tooth 21 with a crown-root fracture. a conservative treatment was undertaken. Under local anesthesia, the fractured coronal fragment of the maxillary left central incisor was gently removed, exposing the vital pulp. Then, a cervical pulpotomy was performed aiming to achieve apexogenesis. Pulpotomy was carried out with a diamond bur at high speed under normal saline irrigation (12), and a calcium hydroxide paste wad used to cover the pulp tissue (12). Afterwards, the coronal fragment was bonded with a rigid splint and light-cured composite resin (TPH Spectrum; Dentsply Ind. e Com. Ltda., Petrópolis, RJ, Brazil). Subsequently, the teeth were splinted with a coaxial wire and composite resin. The parents and the patient were informed about the importance of maintaining meticulous oral hygiene and regularly returning for clinical and radiograph follow-up.

The splint was removed after 2 weeks and the tooth was assessed for mobility. Surprisingly, the tooth was not mobile even after the removal of splint. Pulp vitality of both central incisors was checked again and both teeth gave vital responses to the tests. The teeth were followed up clinically and radiographically during 1 year.

One year after the initial procedures, the radiographic examination showed a periapical lesion on the maxillary left central incisor and no evidence of complete root formation. The root canal was prepared chemomechanically and dressed with a calcium

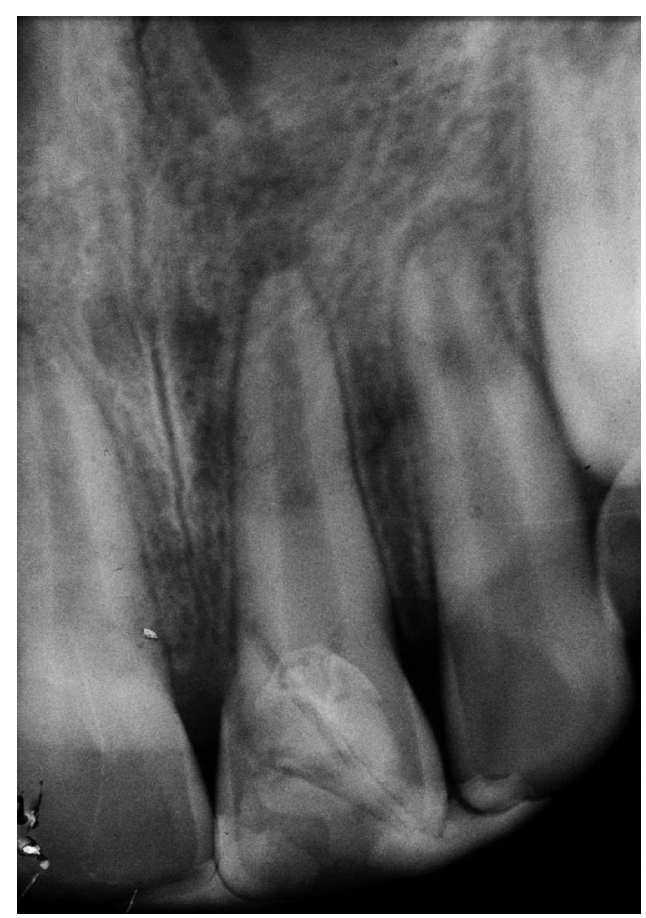

Figure 2. Complicated crown-root fracture on tooth 21. 
hydroxide-based paste containing polyethyleneglycol (Calen; S.S. White Artigos Dentários Ltda., Rio de

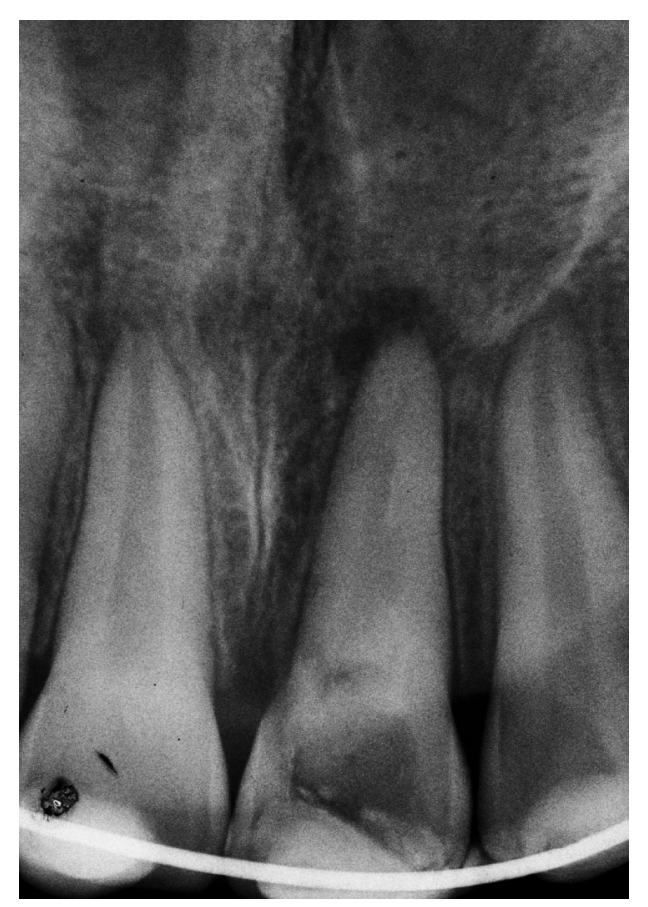

Figure 3. Calcium hydroxide dressing to induce apexification on tooth 21 .

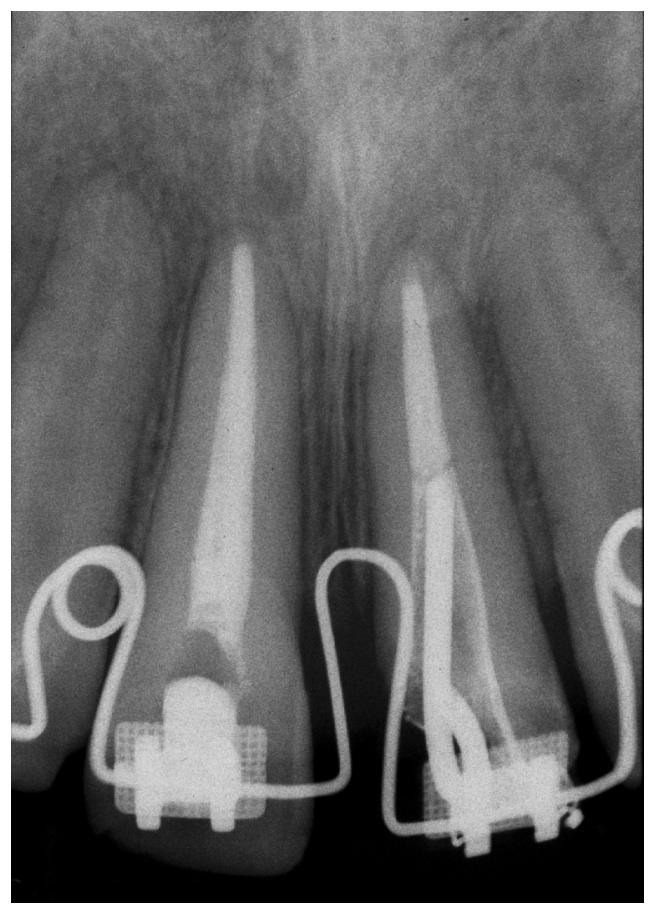

Figure 5. Temporary intracanal post and appliance used for orthodontic extrusion of the root fragment of tooth 21 .
Janeiro, RJ, Brazil). The intracanal medication was changed at 1, 3 and 6 months aiming at apexification (Fig. 3) and, thereafter, the endodontic treatment was concluded (Fig. 4).

As the maxillary left central incisor exhibited normal healing, the orthodontic extrusion was initiated. A temporary intracanal post was cemented and the fractured tooth was restored with composite resin (TPH Spectrum; Dentsply Ind. e Com. Ltda.). Brackets were placed from the maxillary right canine to the left canine and a low intensity force was applied (Figs. 5 and 6).

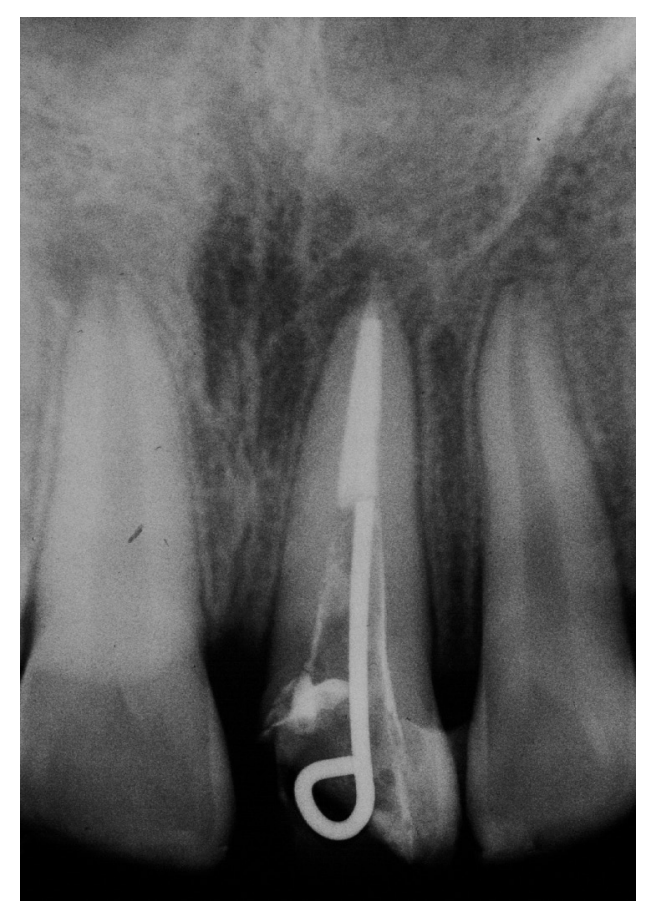

Figure 4. Definitive root canal treatment with the temporary intracanal post cemented on tooth 21 .

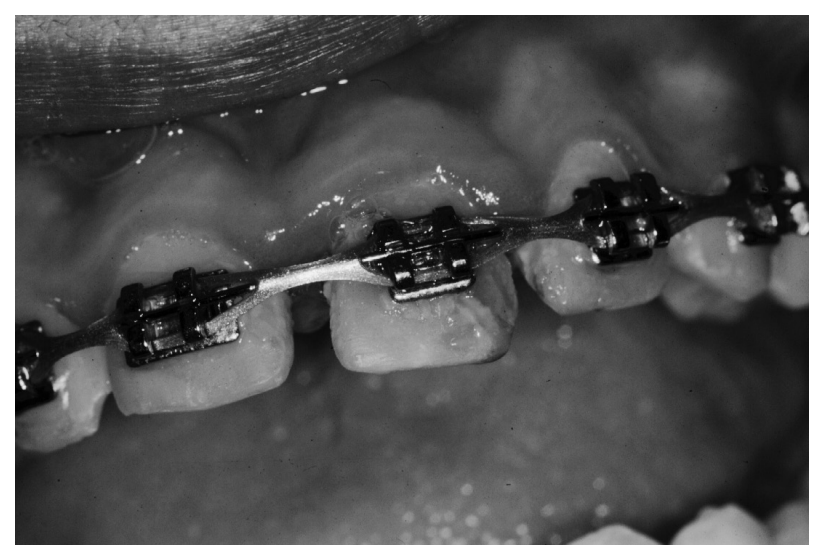

Figure 6. Intraoral view of the orthodontic extrusion with brackets. 
After approximately 16 weeks, extrusion was completed, and the tooth was restored with a post-core system and a prosthetic crown.

On examination at 1 year and 8 months after the trauma, the maxillary left central incisor presented pulp necrosis and conventional endodontic treatment was performed. Follow-up was conducted regularly during 3 years after the trauma. Clinical and radiographic examination showed healthy tissues and teeth, and no evidence of apical periodontitis. Both teeth presented satisfactory functional and esthetic outcomes.

\section{DISCUSSION}

According to a Brazilian retrospective study (13), male individuals suffer significantly more traumatic dental injuries in the permanent dentition than females (2.5:1 ratio) (13), probably because they are more frequently engaged in physical activities involving physical contact. Traumatic dental injuries in the permanent dentition were observed with a high frequency among the 6- to 10-year-old children (13). The majority of traumatic dental injuries involved the maxillary central incisor $(65.65 \%)$ and complicated crown-root fractures were present in $1.35 \%$ of the cases (13).

Currently, several alternative treatments for teeth with subgingival fractures have been proposed (2$4,11,14-16)$. The main objective of the treatment consists in exposing the fracture margin to a supragingival level, so that clinical restoration procedures can be conducted without contamination with blood and saliva $(2,3,9,10)$.

Exposure of the fracture dental margin may be achieved with a gingivectomy and osteotomy or surgical extrusion of the root fragment after the endodontic treatment. Gingivectomy and osteotomy are simple and rapid procedures that allow the fracture restoration soon after the injury and may preserve pulpal vitality. However, it is not indicated in areas where esthetics is required, as these procedures decrease crown-root ratio $(2,4)$. Surgical extrusion is a one-step and less timeconsuming procedure that allows for examining the root fractured surface to look for other potential fractures, once the tooth is intentionally extruded, repositioned and splinted. Nevertheless, pulp vitality is not preserved and a $12 \%$ risk of external root resorption; even though, some authors have reported that this method has good prognosis $(3,9)$. The intentional replantation technique is the deliberate extraction and reinsertion of a tooth into its socket. This is a safe and rapid method that preserves the crown-root ratio and permits the finishing of restoration at the same time, however the pulp vitality is not preserved and the periodontal ligament may fail to attach to the root surface, increasing remarkably the risk of root resorption (4).

Caliskan et al. (9) considered the surgical technique a success in extruding teeth with crownroot fractures because no clinical signs of periapical damage, ankylosis or marginal bone loss were observed. In their study, only $5 \%$ of the cases presented external root resorption within 3 years. The low incidence of external root resorption may be attributed to the use of calcium hydroxide dressing for 3 months before the final obturation (9).

In the present case, low-intensity orthodontic extrusion of the root fragment was the treatment of choice, considering factors such as crown-root ratio, thickness of dentin walls as well as the apical and pulpal conditions. The orthodontic extrusion technique consumes more time, since it is generally necessary 5 weeks to achieve 2-3 $\mathrm{mm}$ of extrusion, followed by a retention period of 8-10 weeks (3).

Incomplete root formation may result from traumatic dental injury during the maturation of permanent teeth. One of the main challenges in performing root canal treatment in immature permanent teeth with wide-open apices is obtaining a seal within the root canal system. The wide-open foramen results in a large volume of filling material and possible formation of voids and gaps between the material and canal walls; consequently, a compromised seal may result (6).

Conventional therapy to traumatic dental injuries with wide open apices includes the use of a dressing with a calcium hydroxide paste in an attempt to form a hard tissue apical barrier promoting apexification, and induce more favorable conditions to the conventional endodontic treatment $(2,3,5,6,8,10)$. Literature recommends the therapy with calcium hydroxide in traumatized teeth to reduce the risk of external root resorption, even in teeth with closed apices $(2,3,9,14)$.

Calcium hydroxide has been shown to decrease inflammatory root resorption $(6,14)$. However, the mechanism of action of calcium hydroxide in inducing formation of an apical barrier remains controversial. It appears that the high $\mathrm{pH}$ and the low solubility in water of calcium hydroxide paste are responsible for its antimicrobial activity and its ability to induce hard tissue formation (6). Despite the clinical success, it has disadvantages, such as the need for good patient 
compliance and multiple appointments extending over a long period of time (from 3 to 24 months) $(5,6)$.

The present clinical report demonstrated the need of a multidisciplinary intervention during the treatment of traumatized teeth. Orthodontic extrusion and root canal treatment using calcium hydroxide dressing were successful in repairing the periradicular tissue of a crown-root fracture in permanent tooth with open apex.

\section{RESUMO}

Este relato de caso apresenta os procedimentos clínicos envolvidos no tratamento de um caso de fratura corono-radicular complicada de um incisivo superior esquerdo com ápice aberto de um paciente de 10 anos de idade devido à queda da própria altura. O tratamento envolveu pulpotomia cervical e fixação do fragmento. Após 1 ano, os exames clínicos e radiográficos demonstraram necrose pulpar e lesão perirradicular associada. $\mathrm{O}$ tratamento endodôntico foi realizado com a utilização de pasta de hidróxido de cálcio, obturação endodôntica e extrusão ortodôntica. Após aproximadamente 16 semanas, o processo de extrusão foi finalizado e o dente restaurado com pino e coroa protética. Após acompanhamento de 3 anos, não havia evidência de lesão perirradicular e o dente estava estética e funcionalmente satisfatório.

\section{REFERENCES}

1. Andreasen JO, Andreasen FM. Textbook and color atlas of traumatic injuries to the teeth. 4th ed. Oxford: Blackwell;2007.

2. Turgut MD, Gönül N, Altay N. Multiple complicated crown-root fracture of a permanent incisor. Dent Traumatol 2004;20:288-292.

3. Olsburgh S, Jacoby T, Krejei I. Crown fractures in the permanent dentition: pulpal and restorative considerations. Dent Traumatol 2002;18:103-115.

4. Wang Z, Heffernan M, Vann Jr WF. Management of a complicated crown-root fracture in a young permanent incisor using intentional replantation. Dent Traumatol 2008;24:100-103.

5. Oliveira TM, Sakai VT, Silva TC, Santos CF, Abdo RCC, Machado MAAM. Mineral trioxide aggregate as an alternative treatment for intruded permanent teeth with root resorption and incomplete apex formation. Dent Traumatol 2008;24:565-568.

6. Rafter M. Apexification: a review. Dent Traumatol 2005;21:1-8.

7. Andreasen JO, Borum MK, Andreasen FM. Replantation of 400 avulsed permanent incisors. 3. Factors related to root growth. Endod Dent Traumatol 1995;11:69-75.

8. Safi L, Ravanshad S. Continued root formation of a pulpless permanent incisor following root canal treatment: a case report. Int Endod J 2005;28:489-493.

9. Caliskan MK, Türkün M, Gomel M. Surgical extrusion of crownroot-fractured teeth: a clinical review. Int Endod J 1999;32:146151.

10. Kocadereli I, Tasman F, Güner SB Combined endodonticorthodontic and prosthodontic treatment of fracture teeth. Case report. Australian Dent J 1998;43:28-31.

11. Bach N, Baylard J-F, Voyer R. Orthodontic extrusion: periodontal considerations and applications. J Canadian Dent Assoc 2004;70:775-780.

12. Sheikh-Nezami M, Mokhber N, Shamsian Kh, Saket S. Management of a midroot and complicated crown fracture: a case report. Oral Surg Oral Med Oral Pathol Oral Radiol Endod 2009;107:e65-e67.

13. Guedes AO, Alencar AHG, Lopes LG, Pécora JD, Estrela C. A retrospective study of traumatic dental injuries in a Brazilian dental urgency service. Braz Dent J 2010;21:153-157.

14. Caliskan MK. Surgical extrusion of a completely intruded permanent incisor. J Endod 1998;24:381-384.

15. Fidel RSA, Carvalho RG, Varela $\mathrm{CH}$, Letra A, Fidel SR. Complicated crown fracture: a case report. Braz Dent J 2006;17:14.

16. Turkistani J, Hanno A. Recent trends in the management of dentoalveolar traumatic injuries to primary and young permanent teeth. Dent Traumatol 2011;27:46-54.

Accepted March 28, 2011 